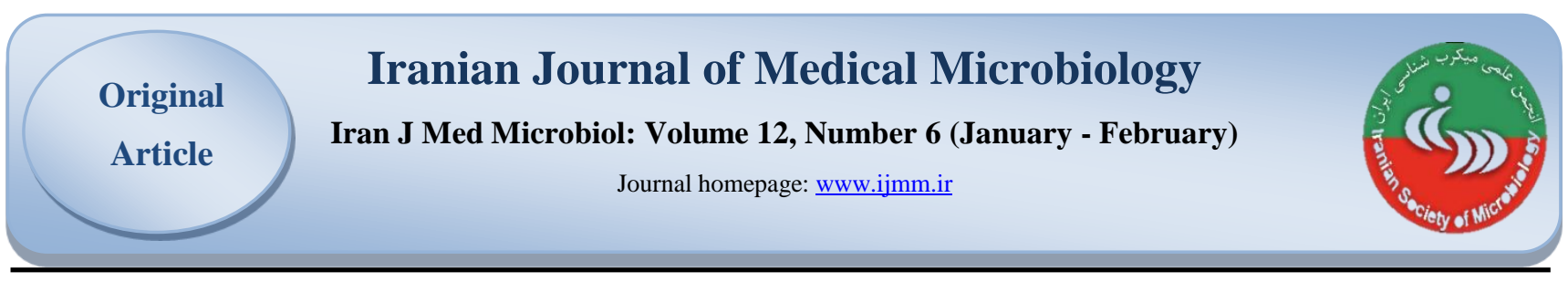

\title{
Detection and Relation of Polyketide Synthase (PKSs) Genes Responsible for Antimicrobial Activity in Terrestrial Cyanobacteria of Lavasan
}

\author{
Roghaye Sadat Hosseini ${ }^{1}$, Abbas Akhavan Sepahi ${ }^{2}$, Bahareh Nowruzi ${ }^{*}$ \\ 1. Department of Biology, Science and Research Branch, Islamic Azad University, Tehran, Iran \\ 2. Department of Microbiology, Islamic Azad University, Tehran North Branch, Tehran, Iran
}

\section{Article Information}

\section{Article history:}

Received: 2018/07/23

Accepted: 2019/02/10

Available online: 2019/03/06

\section{Article Subject:}

Microbial Biotechnology

IJMM 2019; 12(6): 419-431

Corresponding author:

\section{Bahareh Nowruzi}

Department of Biology,

Science and Research Branch,

Islamic Azad University,

Tehran, Iran

Email:

bahare77biol@yahoo.com

Use your device to scan and read the article online

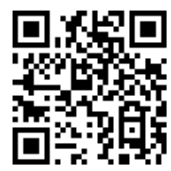

\section{Abstract}

Background and Aims: Cyanobacteria are considered as favorable source for new pharmaceutical compounds. To date, the majority of bioactive metabolites isolated from cyanobacteria are either polyketides (PKSs) or non-ribosomal peptides. Despite of several worldwide studies on prevalence of PKSs, none of them included the terrestrial cyanobacteria of the Lavasan. Therefore, this study aimed to detectthe PKS genes and correlation of the presence of these genes with antimicrobial compounds synthesis.

Materials and Methods: Morphological and molecular identification of the terrestrial strains was performed after culture and purification. Amplification of polyketide synthase and phylogenetic trees were used for phylogenetic analysis. Nucleotide and protein sequences were deposited in GenBank. Lastly, to show the correlation of this gene with antimicrobial compounds synthesis, antibiogram bioassay was used.

Results: Phylogentic analysis revealed that most of the identified 16SrRNA genes and PKS domains had more than $90 \%$ similarity to their closest matches in the Gen-Bank. In addition, antibiogram assessment showedthe different pattern of inhibition, indicating the involvement of variety antimicrobial substances.

Conclusions: According to the results of this sudy, it seems the antibiogram bioassay and molecular detection of polyketide synthase genes are useful techniques for the assessment of productive species of natural products and the possible role of polyketide synthase enzyme complexes in the biosynthesis of biologically active compounds.

Keywords: Polyketide synthase (PKSs), Soil cyanobacteria, Antimicrobial activity

How to cite this: 


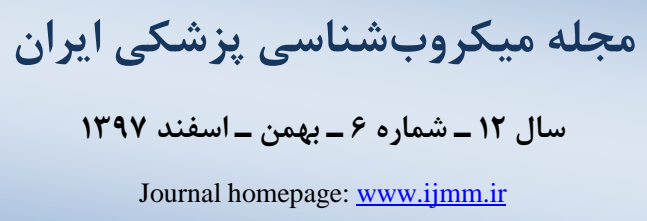

Journal homepage: www.ijmm.ir

\section{شناسايى و ارتباط زنهاى يلىكتيدسنتاز (PKSs) با فعاليت ضدميكروبى در سيانوباكترىهاى خاكزى لواسان}

رقيهسادات حسينى'، عباس اخوانسيهى '، بهاره نوروزى ا"*

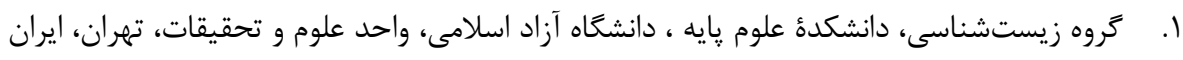

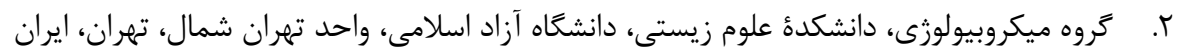

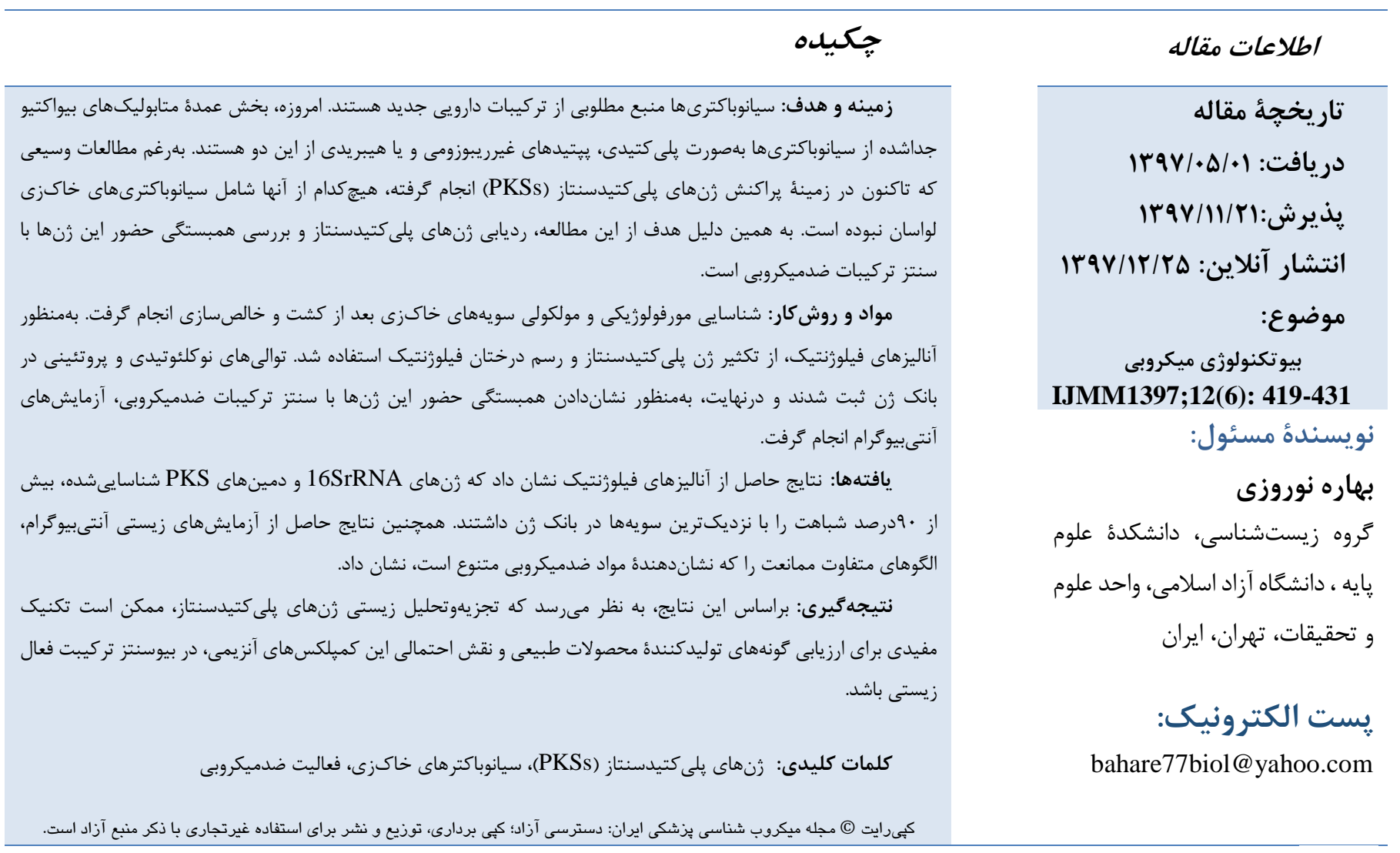

مقلدمه

مانند ونكومايسين، ينىسيلين و اريترومايسين و همجنين عوامل

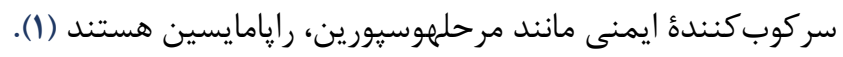
تركيبات فعال زيستى سيانوباكتريايى، داروهاى مفيد و جديدى را

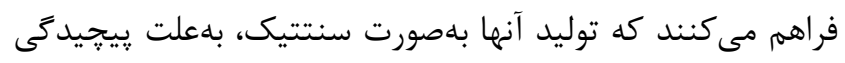
ساختمانشان مشكل است. تعداد فراوانى از متابوليتهاى ثانوئٔ

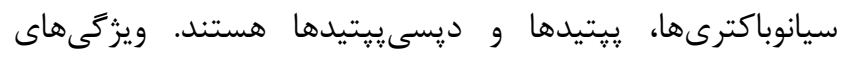

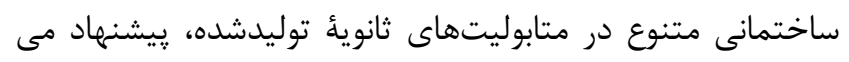

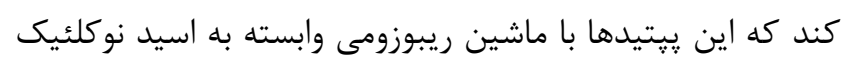

سيانوباكترهاى خاكزى (إيدافيك و اندافيك) بهدليل تثبيت ازت هوا، مهممترين و كاربردىترين ريزجلبكهايى هستند كه امروزه در بيوتكنولوزى مطرح هستند. اين ميكرواركانيسمها، شاخئ

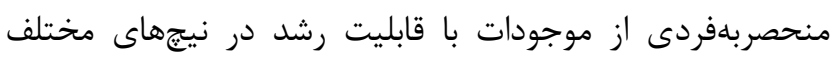
رقابتى بوده و درنتيجه بهعنوان منابع مطلوبى از تركيبهاى فعال

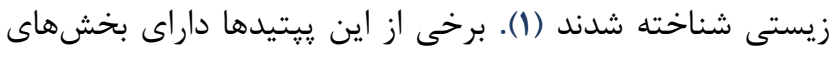

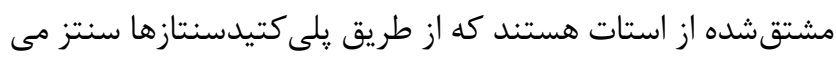
شوند و مسئول سنتز بسيارى از آنتىبيوتيكهاى شناختهشدهاى 
از تركيبهاى آنتىبيوتيكى هستند. بيشتر اين متابوليتهاى آنتى

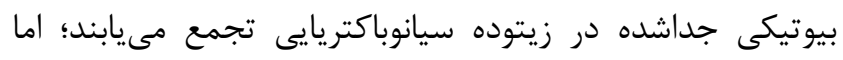
بررسىها نشان مىدهد كه سيانوباكترىها همجنين مى توانئن

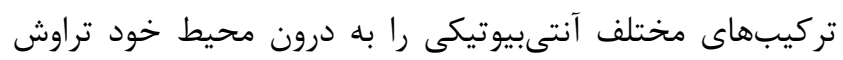

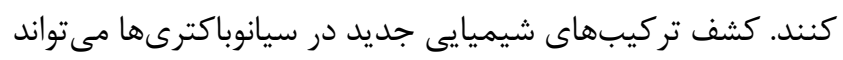

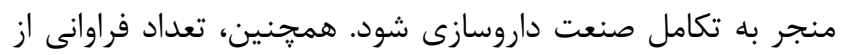
اين تركيبها كانديداى خوبى در كشاورزى و صنعت، بهويزه

داروسازى هستند (ه).

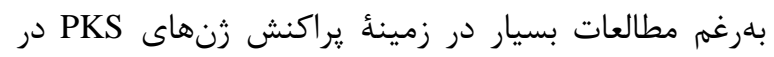

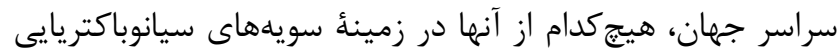

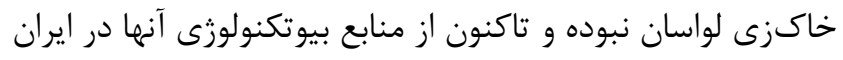

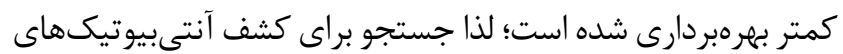
جديد و بررسى حضور زنهاى PKS با سنتز تركيبات ضدميكروبى

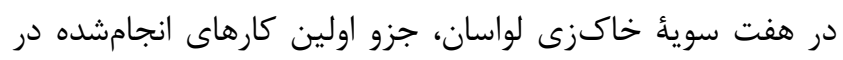

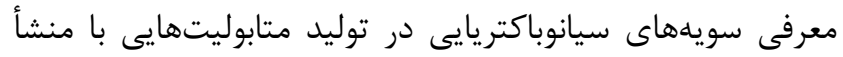
دارويى است. در اين راستا جستجو براى آشكارسازى حضور زن رناي

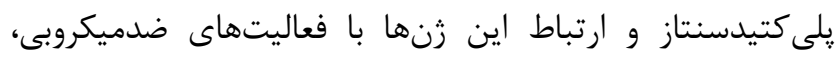

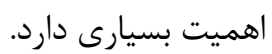

\section{مواد و روشها}

\section{موقعيت جغرافيايى مكان نمونهبردارى شده، روش}

\section{نمونهبردارى و كشت}

نمونهبردارى از بخش فوقانى خاك مناطق مختلف لواسان تا

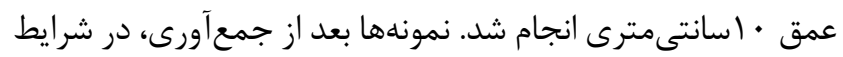

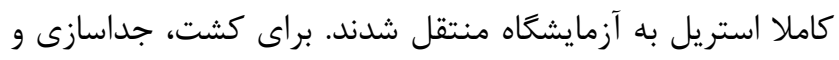
خالصسازى نمونههاى سيانوباكترىها از محيط كشت جامد إندائن

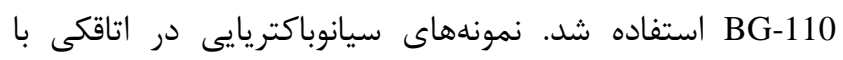

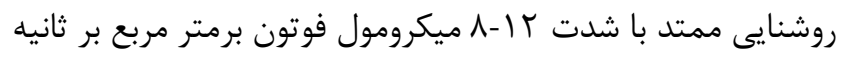

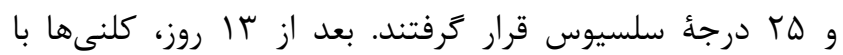
رنخَهاى مختلف روى محيط كشت مشاهده شدند. بهمنظور

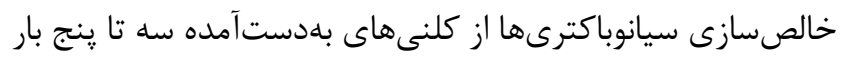

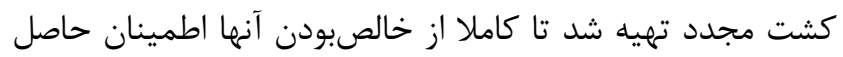
شود. يس از خالصسازى، براى انجام آزمايشهاى مولكولى، مى مانى بايست از اكزنيكبودن نمونهها اطمينان حاصل كرد. به همين دليل إليل

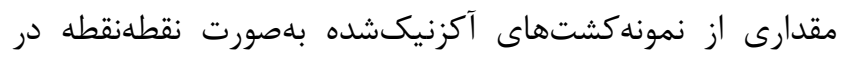
محيط كشت R2A كشت شدند. تلاش شد از تمام سطح كشت

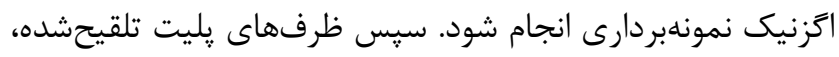

سنتز نمىشوند. توليد اين محصولات حتى در حضور بازدارندههاى

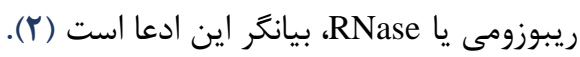
يلى كتيدها، گروه مههم ديكرى از محصولات طبيعى هستند.

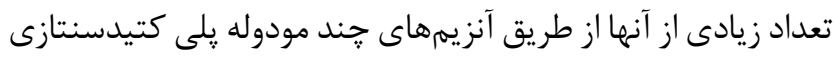
سنتز مىشوند. با وجود تنوع ساختمانى بسيار بالاى اين فرآور آنهدها، فقط دو بلوك ساختمانى، يعنى استات و يروييونات در سنتز يلى لئى كتيدها سهيم هستند. تنوع بالاى ساختمانى موجود در اين النئ

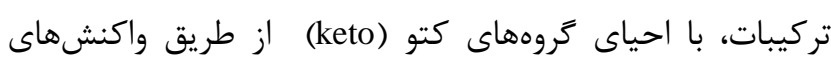
هيدروكسيلاسيون و كَليكوزيلاسيون حاصل مىشود. هر مودول يلى كتيدسنتاز، مسئول مشاركت يك واحد استات يا يروييونات

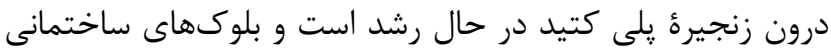

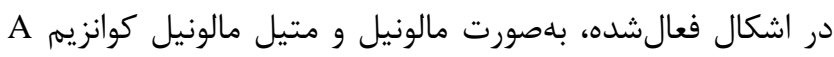
هستند. جَكونكَى توليد محصول از طريق اين آنزيمها كمى يبيجيده

$$
\text { و به شرح زير است: }
$$

هر مودول يلى كتيدسنتاز، به دمينهاى ضرورى و در برخى

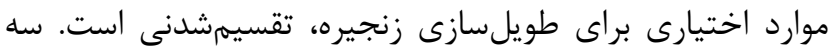

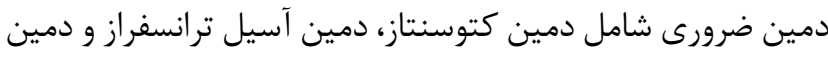

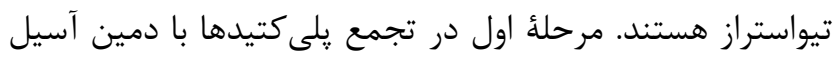

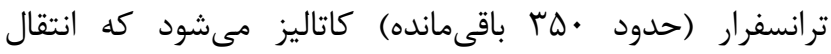

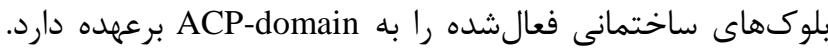

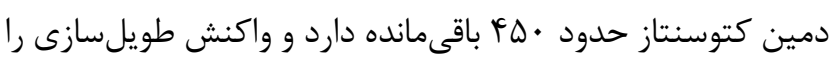
در سنتز يلى كتيدها كاتاليز مى كند. واكنش با انتقال زنجيرة كتيديد از يروتئين حامل آسيل يك مودول بالادست به سايت فعال دمين

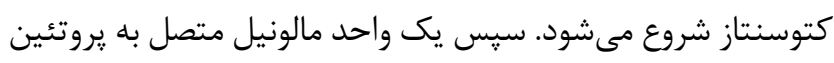

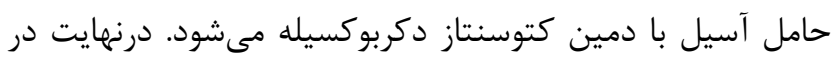
دمين تيولهشده، آزادسازى فرآورده در بايانهُ C انجام مىشود (باّ). تحقيقات پيرامون سيانوباكترىها در صنعت داروسازى در

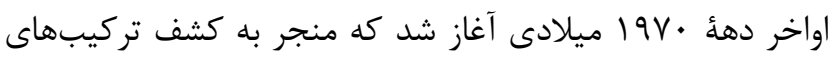

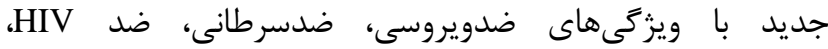
ضدباكتريايى، ضدقارجى و سيتوتوكسيك در كاربردهاى كليني

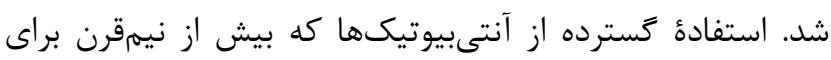

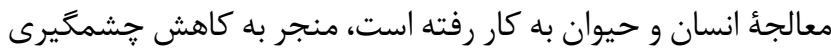

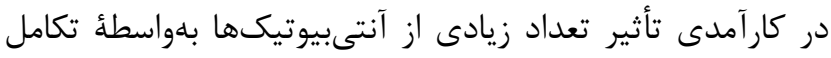

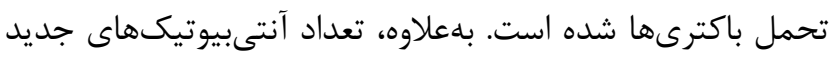

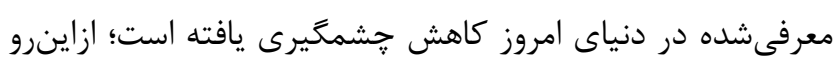
جستوجو براى يافتن متابوليتهايى با خواص آنتىبيوتيكى جديد، درائ

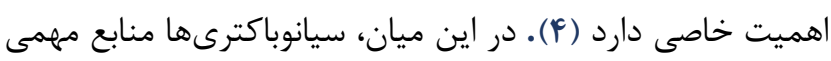


براى تكثير توالى زن 19SrRNA با استفاده از يرايمرهاى

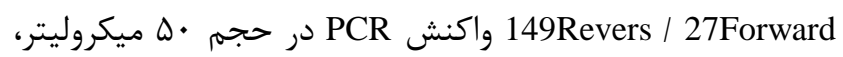

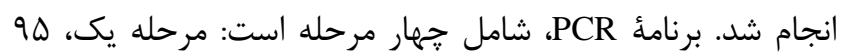

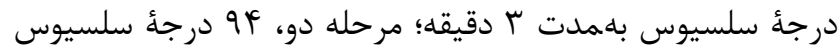

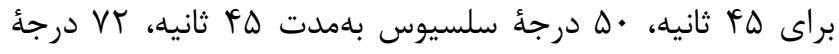

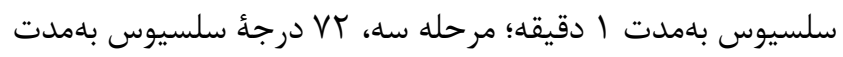

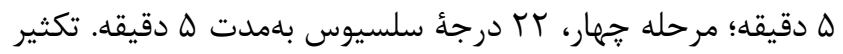
زن PKS، با استفاده از يرايمرهاى اليكونوكلئوتيدى دزنره DKReves/DKForword

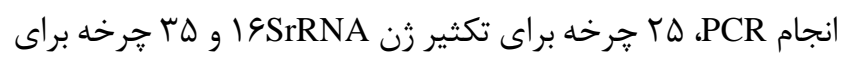

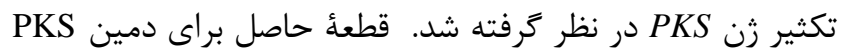

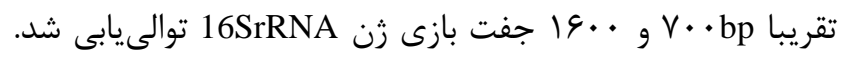

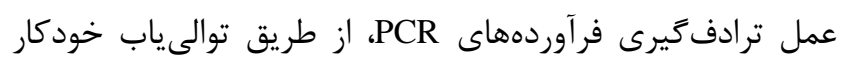
مدل Beckman از سوى شركت Microgene (كرهجنوبى) انجام

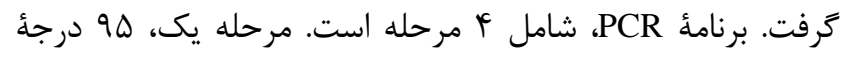

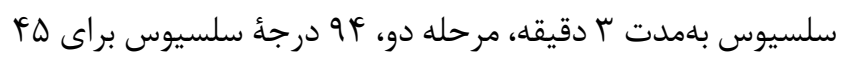

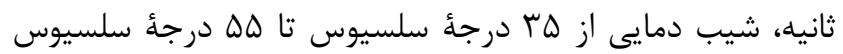

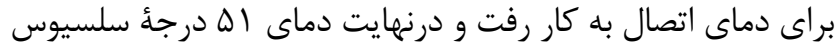

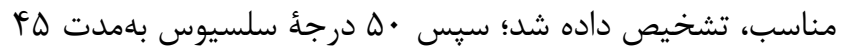

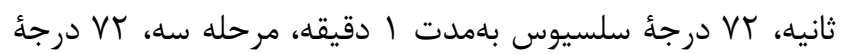
سلسيوس بهمدت بادقيقه و مرحله جهار شامل r ب درجة سلسيوس

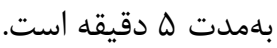

در دماى Tr درجة سلسيوس بلهمدت ينج تا هفت روز يا در دماى

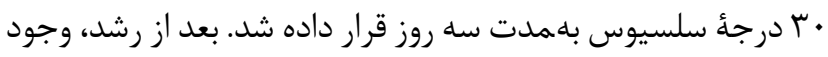
يا نبود كلنى در اطراف هر نقطه جكى شد. درنهايت نمونههاى اگزنيك بلمنظور آزمايشهاى مولكولى، استفاده شدند (9).

\section{شناسايى براساس ويزَّى هاى مورفولوزيك نمونهها} شناسايى مورفولوزيك سيانوباكترىها، به كمك ميكروسكوٍ نورى مجهز به ميكرومتر مدرج با اندازءٔ · ا ميكرومتر انجام گرفت.

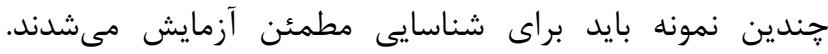

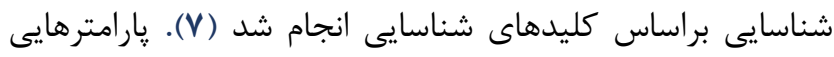
مثل: طول و قطر سلولهاى رويشى، هتروسيست و آكينت، مورفولوزى سلول انتهايى، مسافت بين هتروسيست و نزديكترين

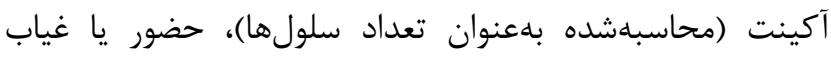

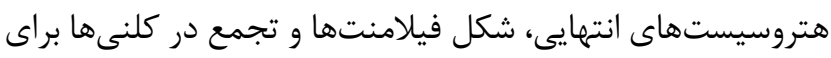
بخشهاى مورفولوزيك بررسى شدند.

\section{غربالَرى حضور ثن PKS در نمونههاى سيانوباكترى}

\section{Dدف استخراج DNA}

استخراج DNA به روش CTAB انجام گرفت. براى بهدست

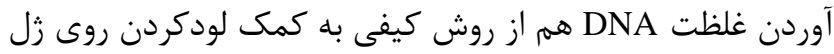

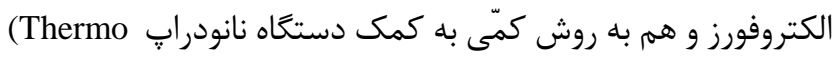
Scientific) spectrophotometer

DNA استخراجشده، كيفيت بالاى باندها را تضمين مى كند (A).

انجام واكنش PCR براى تكثير زن PKS و 16SrRNA

جدول ا. يرايمرهاى اليكونوكلئوتيدى زنهاى هدف و برنامهاى استفادهده در اين مطالعه

\begin{tabular}{cc}
\hline is & \\
\hline \multirow{2}{*}{16 SrRNA } & 27F (5'-AGAGTTTGATCCTGGCTCAG-3') \\
& 149R (5'-CTTCGCCTCTGTGTGCCTAGGT-3') \\
PKS & DKF(5'-GTGCCGGTNCCRTGNGYYTC-3') \\
& DKR(5'-GCGATGGAYCCNCARCARYG-3') \\
\hline
\end{tabular}

(شكافهاى موجود در توالىها يس از همرديفسازى حذف شد. درخت فيلوزنى با استفاده از آناليز Maximum Likelihood و Neighbour-Joining ساخته شد. انجام يك سلسله تصحيحات از جمله ادغام و درج فراوانىهاى حاصل از دو روش Neighbourو و آناليز Maximing Likelihood 16SrRNA نسخة ' Snagit Editor Aquifexaeolicus

\section{ساخت درختان فيلوزنتيك و ثبت زن}

جستجوى بلاست نوكلئوتيد براى يافتن توالىهاى مشابه زن 16S rRNA است، انجام شد. توالى زن به همراه ديخر توالىهاى مشابه گرفتهشده از GeneBank با استفاده

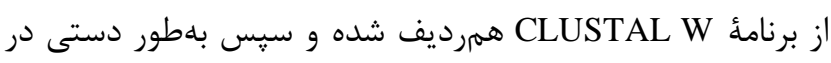

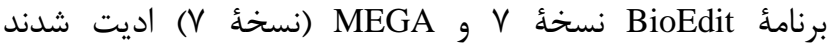


Staphylococcus aureus (PTCC سه باكترى گرم مثبت سه باكترى كرم Bacillus cereus (PTCC 1015) ، منفى Escherichia coli(PTCC 1047) و Enterobactersp. 638 يك مخمر (ATCC 10231) ياتوزنيك (ATCC 16404) و Fusarium spergillus niger (ATC اين بررسى استفاده شدند. براى كشت باكترىهاى f باساعته، از

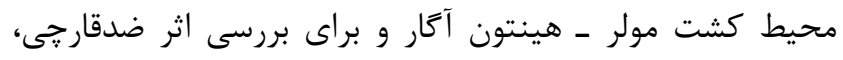

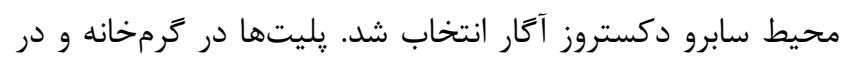
دماى TV درجهُ سلسيوس بلهمدت TF ساعت براى باكترىها و و

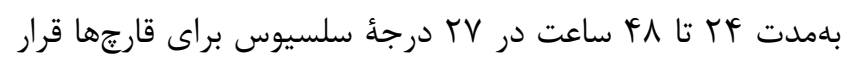
گرفتند. قطر مناطق بازدارنده رشد شامل قطر ديسك كاغذى با خط كش اندازهخيرى و با ميلىمتر بيان شد.

\section{روش هاى آمارى}

يس از انجام آزمايشها، آناليزهاى آمارى دادههاى حاصل از

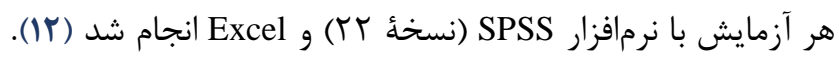
تمام دادهها حاصل از نتايج سه تكرار است. تفاوت معنى داردار بين عوامل اندازهخيرىشده با آناليز واريانس يكىطرفه با حدود اطمينان

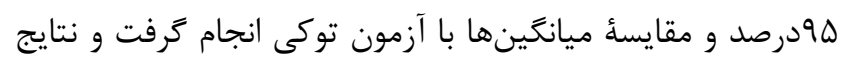

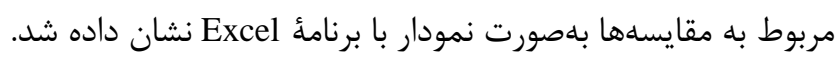

\section{بافتهها}

\section{نتايج حاصل از بررسى تاكسونومى مورفولوزيكى و مولكولى سيانوباكترى هاى موجود در خاكى لواسان}

در كل بr سوئٔ سيانوباكترى مختلف متعلق به سه خانواده

Scytonemataceae Nostocaceae جنس هاى يافتشده شامل سويdهاى مختلف Scytonema Nostoc و Calothrix كزارش شدند. نتايج حاصل از سه بار تكرار تكثير زن نشان داد كه فقط جهار سوية متعلق به جنس نوستوك،

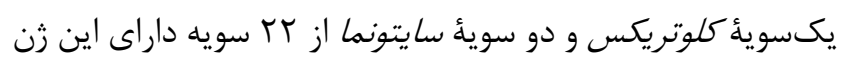

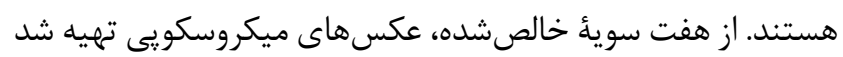

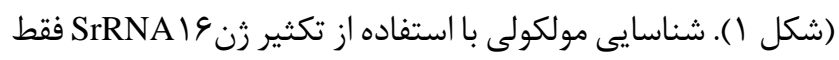
روى هفت سويه انجام گرفت.
گروه خارجى (Outgroup) استفاده شد. براى جلوگيرى از تك شاخهاى درونگروهى، از توالىهاى 16SrRNA, Chloroflexus Agrobacterium tumefaciens, Escherichia coli ،aurantiacus استفاده شد. صحت روابط بين تاكسونها با آناليز Bootstrap تشكيلشده از . ․ نمونه تكرار انجام گرفت. جستجوى بلاست X براى يافتن توالىهاى مشابه زن PKS كه در رايعاه دادههاى

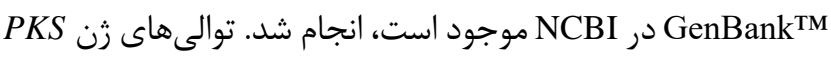
بلدستآمده در اين بررسى به همراه ديخر توالىهاى مشابه

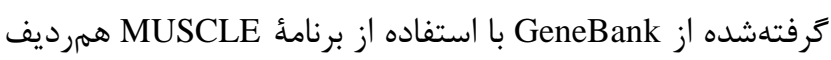
شدند. براى ساختن درخت از برنامd IQ-Tree، با استفاده از برنامة Maximum likelihood تصحيح شد. صحت روابط بين تاكسونها با آناليز Bootstrap

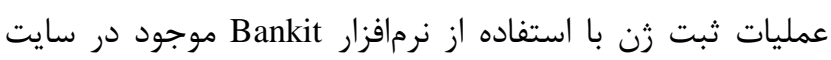
http://www.ncbinlm.nih.gov/WebSub/ttool=genbank كرفتن كد دسترسى توالىهاى نوكلئوتيدى توالىيابىشد، هفت سويه در يايعاه داده DDBJ ثبت شده و به آن رمز يا شمارهاى تعلق كرفت كه مخصوص آن توالى است.

\section{بر رسى تأثير هاى ضدميكروبى با استفاده از روش انتشار}

در اين روش از ديسكهاى كاغذى آغشته به عصاره سيانوباكتريايى حلشده در حلال متانول كه براساس مطالعات ״يشين برترين حلال در مطالعات ضدميكروبى است، بهعنوان بازدارندهُرشد باكترىها و قارجها استفاده شد. براى آمادهسازى عصارههاى سيانوباكتريايى در فاز ايستايى رشد (روز ها ) به كار رفت

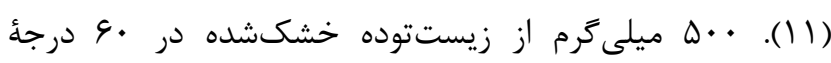

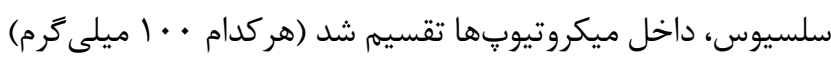

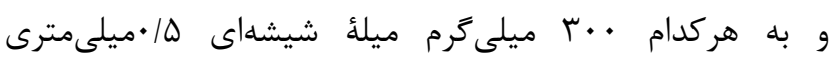
و و يك ميلى ليتر حلال (disruptor beads, • Scientific Industries) اضافه شد. سيس ورتكس بلمددت نيمساعت صورت گرفت تا ديواره

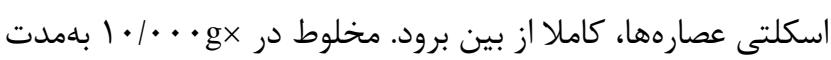

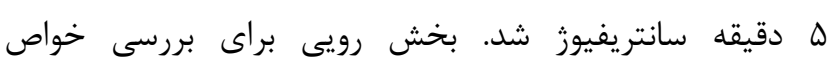
ضدميكروبى در أ درجه سلسيوس نخهدارى شد (11). 


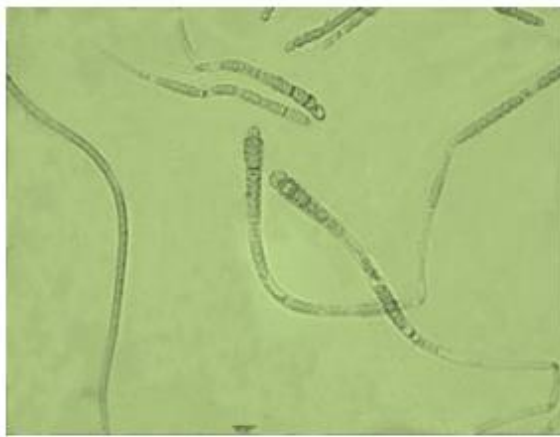

A

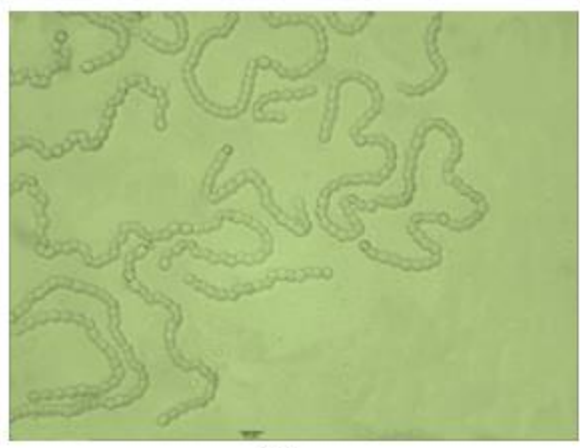

D

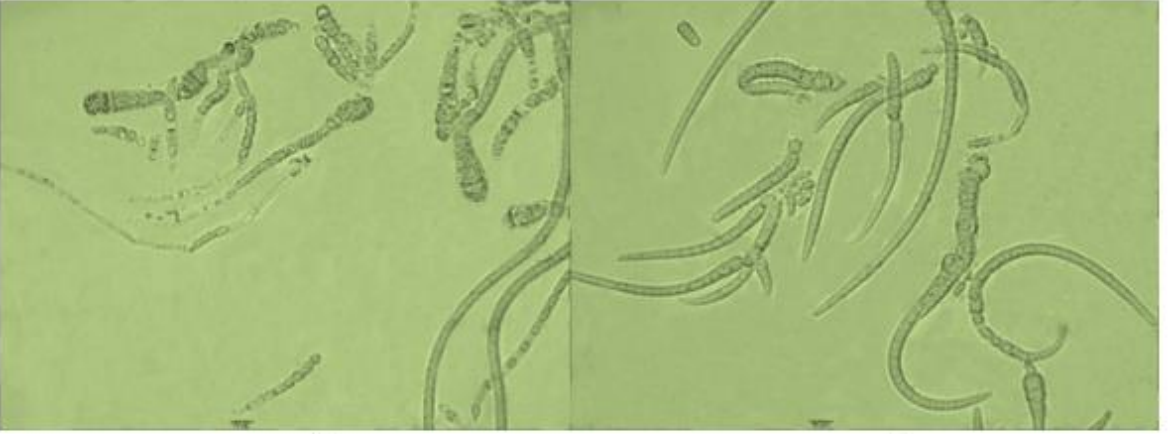

B

C

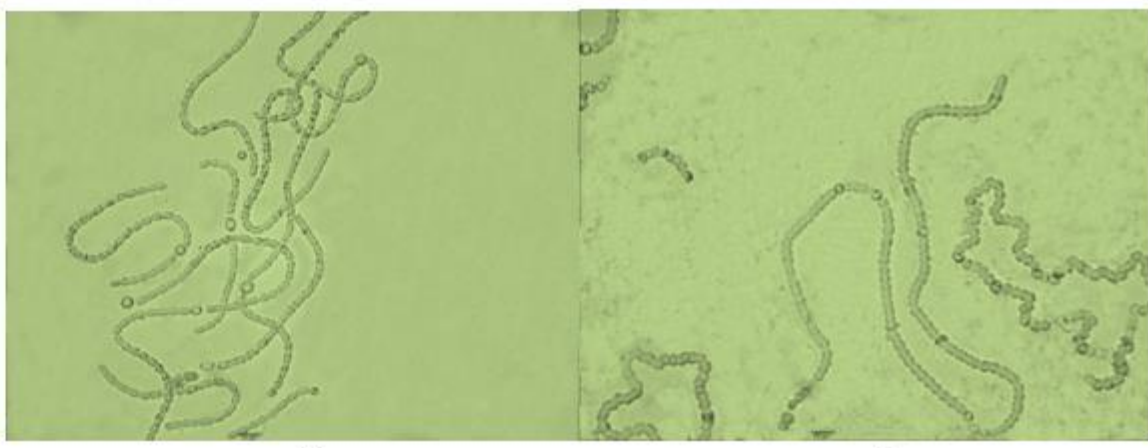

F

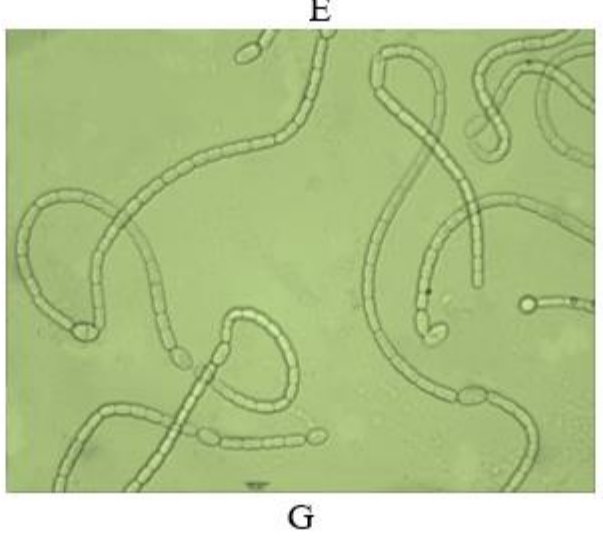

شكل (. شكلهاى سويههاى سيانوباكتريايى بومى يافتشده در خاك لواسان. A:Calothrix sp. F6B: Scytonemasp.Ft11C: Scytonema sp. F12D: Nostoc sp. F16 E: Nostoc sp. F25; F: Nostoc sp. F27G: Nostoc sp. F187

Nostocsp كيرند. به بيان ديخر، اين سويه بيشترين قرابت را با سوية

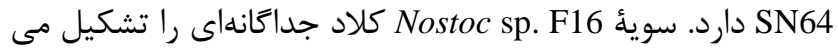

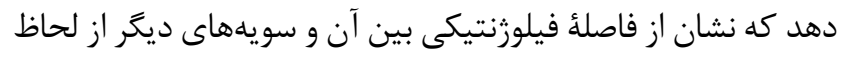

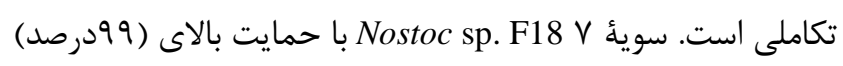
با سويههاى Nostocsp N66 و Nostocsp BN1 خوشهبندى مى شوند و در يك كلاد قرار مى كيرد. سويأ Nostoc sp. F25 با حمايت

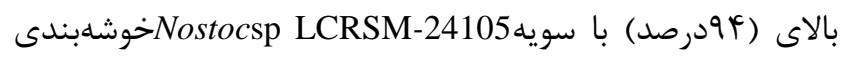

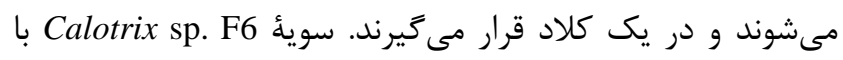
حمايت بالاى Bootstrap (4ودرصد) با سويه خوشهبندى مىشوند و در يك كلاد قرار مى گيرند. به بيان ديكر،

\section{SrRNA نتايج حاصل از آناليز درخت فيلوزنتيك زن} هفت سويه بررسى شده

با توجه به درخت فيلوزنتيك ساختهشده، هر شاخه روابط بين

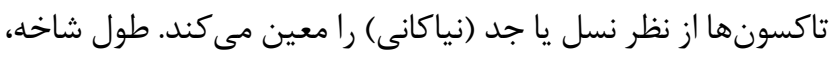

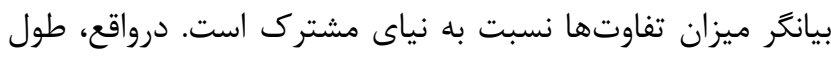
شاخه تعداد تغييرهايى كه در يك شاخه رخ داده را نشان مى دهدد. درخت ساختهشده با روش Maximum Likelihood نشان مىدهد

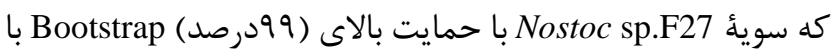
سويأ Nostocsp SN64 خوشهبندى مى شوند و در يك كلاد قرار مى 
Bootstrap

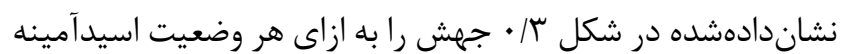
نشان مىدهد. سويههاى مطالعهشده در درخت فيلوزنتيك با حمايت

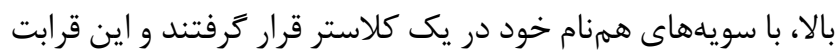
فيلوزنتيك آنها را نشان مى بـدهد.

نتايج حاصل از ثبت توالى نوكلئوتيدى و يروتئينى زنهاى تكثيرشده

توالىهاى نوكلئوتيدى و يروتئينى توالىيابى شده هفت سويه

براساس توالى زن 16SrRNA د PKS در پايگاه دادههاى (DDBJ) ثبت شدند (جدول r). سويههاى خالصشده در باس بانك هرباريوم

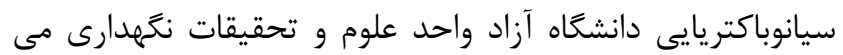
شوند.
سويئ مورد مطالعه داراى بيشترين قرابت با بوئ و Scytonema sp. Ft11 سوئ. Calatrixderestica Bootstrap با حمايت بالاى Scytonema sp. F12 سوئ (99رصد) در يك كلاد خوشهبندى مىشوند (شكل ؟). آناليز فيلوزنى دمينهاى ثن PKS هفت سويئ سيانوباكترى تكثير دمينهاى PKS بهطور موفقيتآميز از DNA الخوى

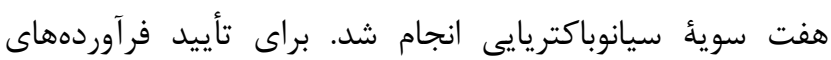
V. ت تكثيرشده دمين PKS، توالىيابى انجام شد. قطعة تقريبا كيلوبازى با دمين آدنيلهشده PKS ترادف

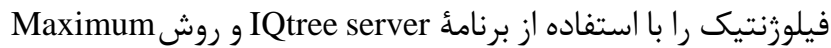
LLikelihood از بانك زن باBLASTx، درخت فيلوزنتيك رسمشده به كمك بعدي برنامئ fig tree تصحيح شد. صحت روابط بين تاكسونها با آناليز

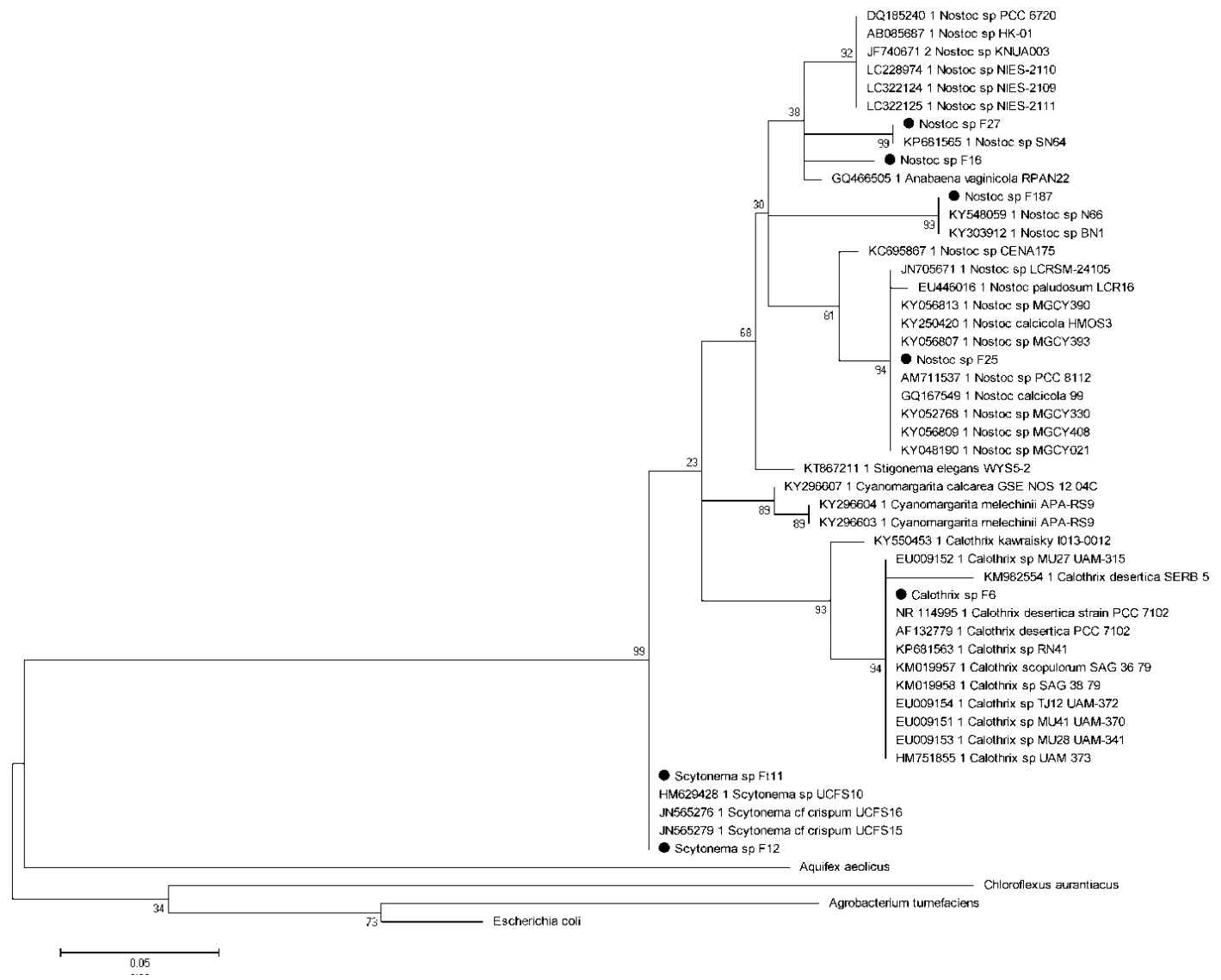

شكل r. شكل درخت فيلوزنتيك را نشان مى نهد. مقياس نشاندادهشه در شكل، نشاندهنده هـ • • جهش به ازاى هر نوكلئوتيد است. نمونهاى مورد مطالعه با 


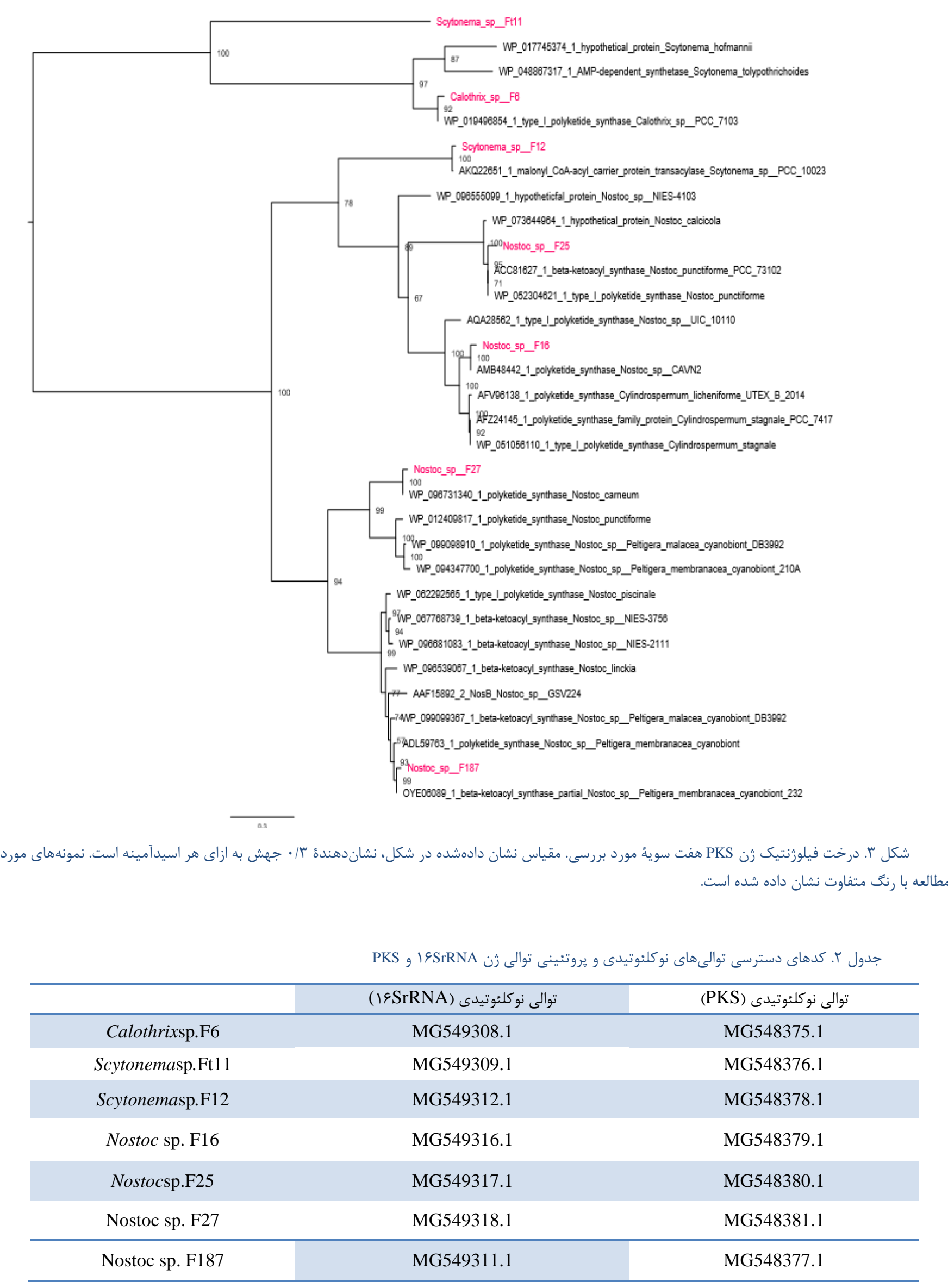


داشتند. در اين ميان تفاوت معنى دارى بين سويههاى Nostoc spp. F16 Scytonema sp.F11

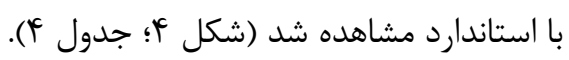
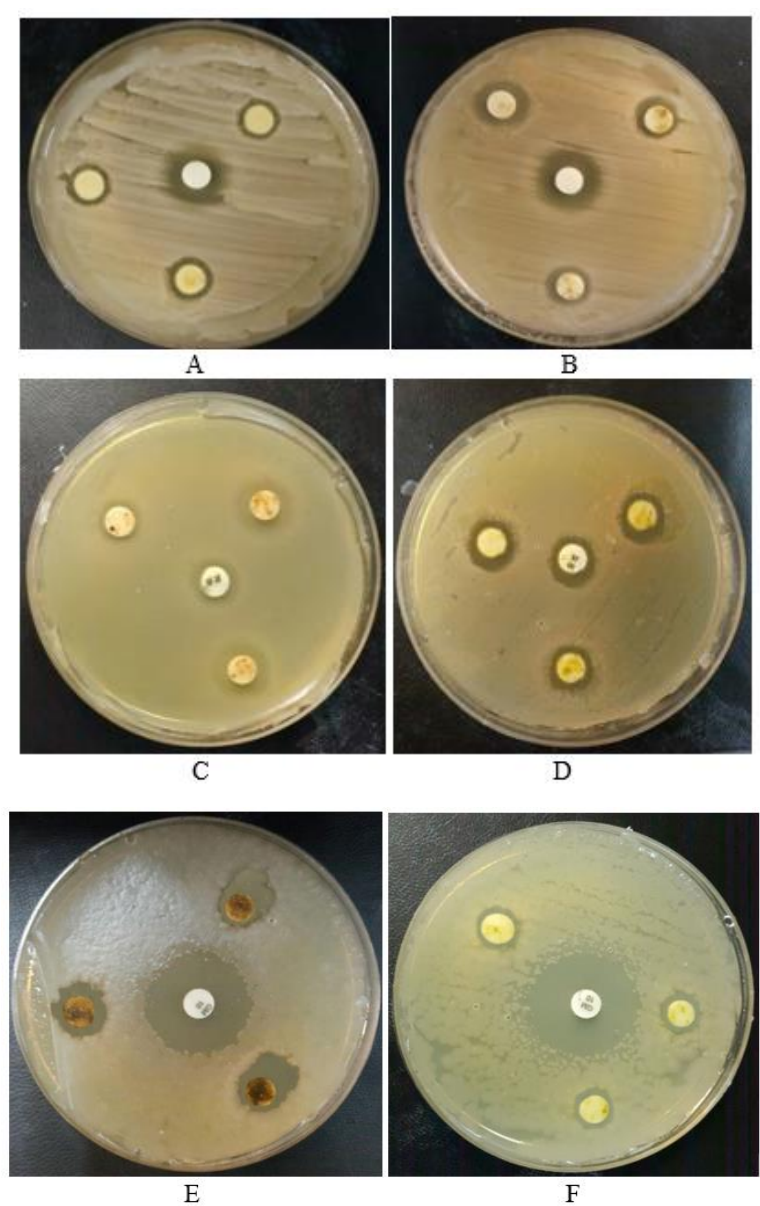

شكل ז'. وجود هاله در نمونه هاى (A) Calothrixsp. F6 و (B) sp. Ft11 Nostocsp.F27 (C) در نمونهاى (F) sp.F16NostocوScytonema sp.F11(E) در مقابل Bacillus

cereus
نتايج حاصل از بررسى اثرهاى ضدباكتريايى و ضد

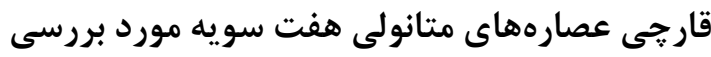
بررسى فعاليت ضدقارجى هفت سويأ بررسىشده نشان داد

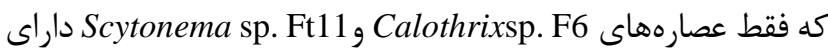
فعاليت ضدقارجى در مقابل Candida albicans بودند (شكل عاع).

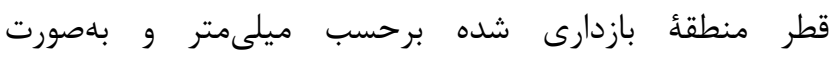
Means \pm SE

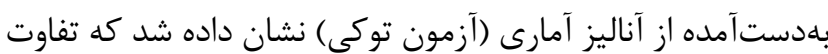

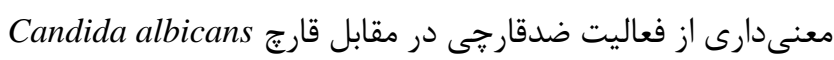

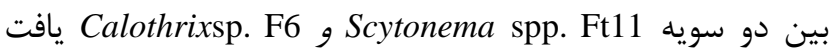
نشد؛ اما با استاندارد تفاوت معنى دارى مشاهده شد. علاوه بر بر آن

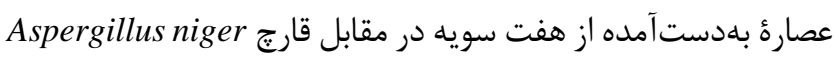

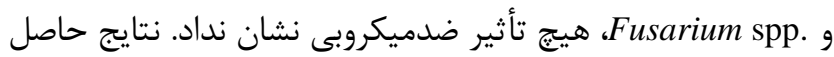

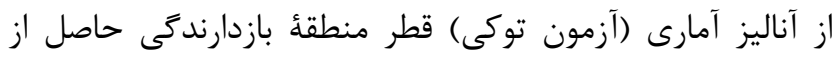

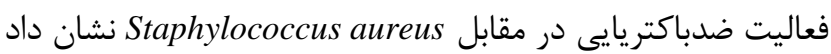

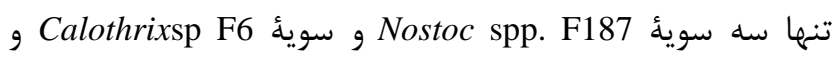
Scytonemasp F12 مورد آزمايش در برابر باكترى Staphylococcus aureus اختلاف

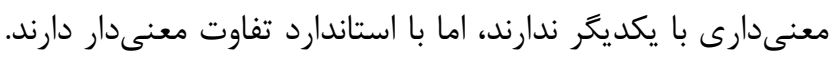

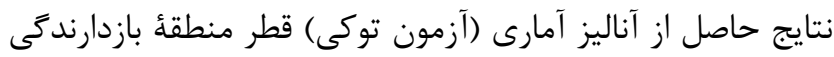
حاصل از فعاليت ضدباكتريايى در مقابل . Enterobacter spp نشان

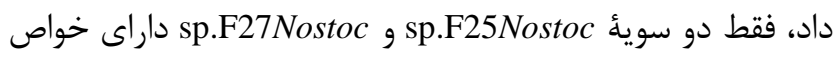

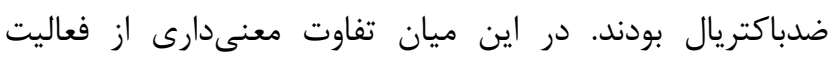
ضدباكتريايى بين دو سوية Nostoc sp.F25 و Nostocsp.F27 و ونان استاندارد يافت نشد (شكل بأب). نتايج حاصل از آناليز آمارى (آزمون توكى) قطر منطقة بازدارندكى حاصل از فعاليت ضدباكتريايى در

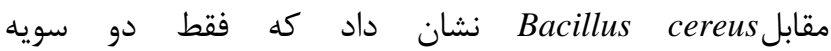
Nostoc spp. F16 و Notonema spp. F11

\section{جدول זّ. ميزان فعاليت ضدقارجى عصارههاى بررسىشده.}

Scytonema sp. Ft 11

Calothrix sp. F6

\begin{tabular}{|c|c|c|}
\hline $1 \pm 0.03$ & $1.3 \pm 0.08$ & Candida albicans \\
\hline
\end{tabular}




\begin{tabular}{|c|c|c|c|c|c|c|c|}
\hline \multirow[t]{2}{*}{$\begin{array}{l}\text { Calothrix } \\
\text { F6 }\end{array}$} & \multirow[t]{2}{*}{$\begin{array}{c}\text { Scytonema } \\
\text { F11 }\end{array}$} & \multirow[t]{2}{*}{ ScytonemaF12 } & $\begin{array}{l}\text { Nostoc } \\
\text { F16 }\end{array}$ & $\begin{array}{l}\text { Nostoc } \\
\text { F25 }\end{array}$ & $\begin{array}{c}\text { Nostoc } \\
\text { F27 }\end{array}$ & \multirow[t]{2}{*}{$\begin{array}{c}\text { Nostoc } \\
\text { F187 }\end{array}$} & \\
\hline & & & & $1.46 \pm 0.17$ & $\begin{array}{lr}1.36 & \pm \\
& 0.06\end{array}$ & & Entrobacter \\
\hline \multirow[t]{2}{*}{$1 \pm 0.17$} & & $1.16 \pm 0.08$ & & & & $1.1 \pm 0.05$ & $\begin{array}{c}\text { Staphylococcus } \\
\text { aureus }\end{array}$ \\
\hline & $1.3 \pm 0.1$ & & $\begin{array}{lr}1.03 & \pm \\
& 0.06\end{array}$ & & & & Bacillus cereus \\
\hline
\end{tabular}

Calothrix parietina, Oscillatoria anguistisima موجودات مختلف ياتوزنيك انجام شده است. بررسى هاى بسيارى در زمينٔ آثار ضدباكتريايى عصارههاى.Spirulina ،Fischerella sp ‘Nostoc sp. CCC537 Anabaena variabilis platensis Synechocystis ‘Nostoc Anabaena ‘Oscillatoria Synechococcus و Nostocales ،Oscilatoriales ،Pleurocapsales ،Chroococales Stigonematales

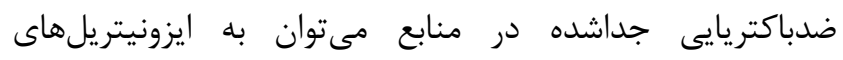
،Norharmane ،Comnostins A-E ،Aoscomin ،Ambiguine Carbamidocyclophanes و اشاره كرد (Y) Lyngbyazothrins بسيارى از يُيتيدهاى حلقوى سيانوباكترىها داراى فعاليت ضدميكروبى ويزه هستند. براى مثال Kawaguchipeptins A و

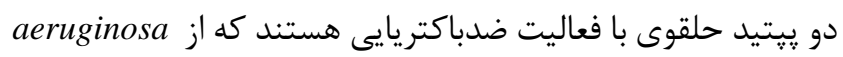

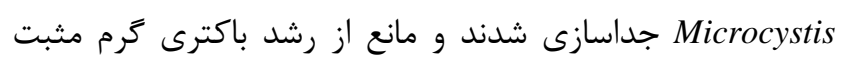
Staphylococcus aureus بلهدستآمده در اين بررسى نشان داد كه عصارههاى جلبكى بعضى

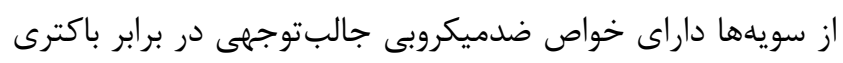
هاى گرم مثبت، باكترىهاى گرم منفى و قارجها بودند. تنوع در

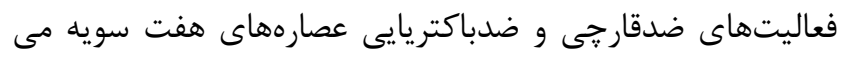
تواند بهواسطة تفاوت در نفوذيذيرى تركيبهاى فعال زيستى درون

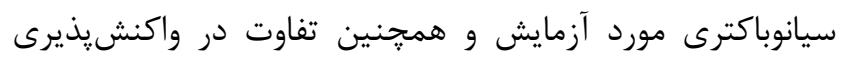
سويههاى مختلف قارجى و باكتريايى در برابر تركيبهاى فعال زيستى موجود در عصاره جلبكى باشند. همانطور كه از از نتايج ييداست، قطر مناطق بازدارندىى عصارههاى حاصل با يكديخر

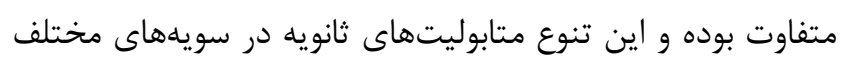

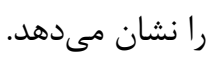

نتايج حاصل از بررسى همبستگى آزمايشهاى آنتىبيوگرام و تكثير رنهاى PKS در هفت سويه سيانوباكتر مطالعهشده، ارتباط

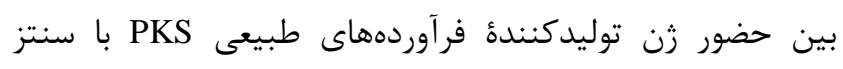

$$
\text { بحث و نتيجه گيرى }
$$

بهدليل فراوانى اكوسيستمهاى طبيعى در ايران يزوهشهاى علمى در زمينههاى مختلف در اين مناطق ضرورت دارد. از بين

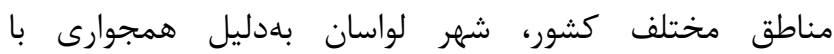

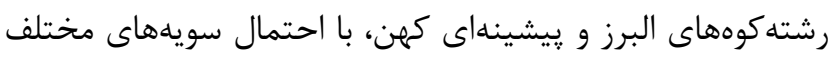

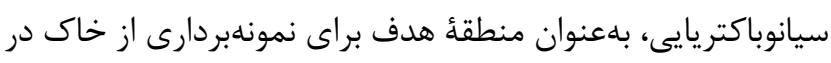

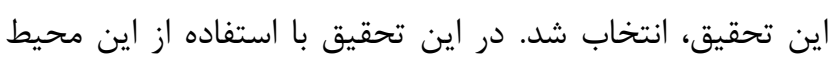
كشت BG-11 تعداد هفت سيانوباكتر جداسازى و خالص شديق شندئ. سيس براى جستجوى زنهاى توليدكننده تركيبات آنتىبيوتيكى، زنهاى PKS فعاليت ضدميكروبى غربال توالىها از آناليزهاى بيوانفورماتيكى و رسم درختان فيلوزنتيك استفاده شد.

آثار ڤزشكى درمانى سيانوباكترىها اولين بار در اوايل • 1ها

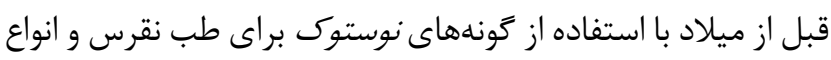

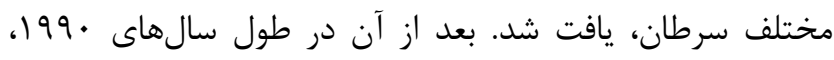

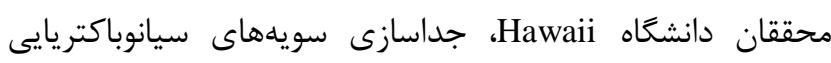
را با هدف كشف فعاليتهاى Anabaenasp و (ر) Microcystis بيولوزيكى مختلف شروع كردند. همجنين آزمايشهايى با هدف شناسايى خواص ضدباكتريايى، ضدقارجى، ضدويروسى (AIDS)، ضدسرطانى، فعاليت ضدمالاريايى، فعاليت بازدارندىى يروتئازى، فعاليت سيتوتوكسيك، فعاليت ضديروتوزوال و فعاليتهاى ديخر انجام شد. درواقع جستجوى سيانوباكترىها بهعنوان منابعى جديد

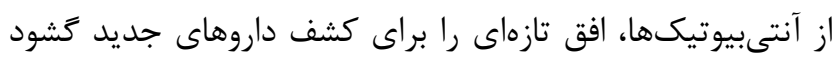
(IV-IV) وسيعى از فعاليتهاى زيستى مانند فعاليتهاى ضدباكتريايى، ضدقارجى، ضدويروسى و و سيتوتوكسيك و در در برخى مواقع

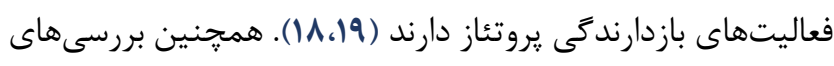

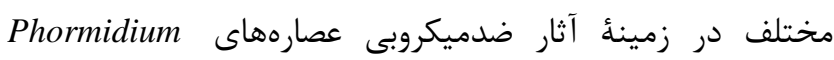
Synechocystis , Anabaena ,Oscillatoria Pseudoanabaen 
مشاهدهده، ممكن است توسط سيستمهايى غير از زنهاى NRPS

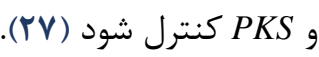

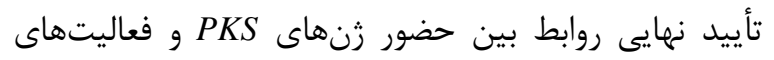

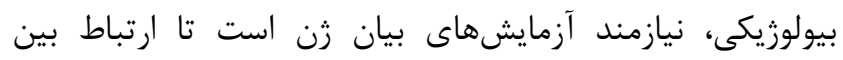

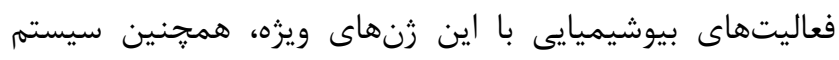

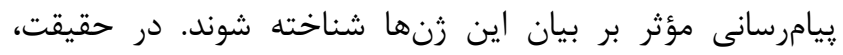

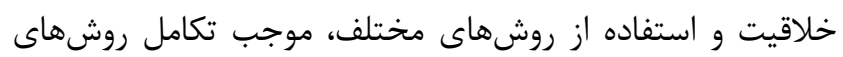

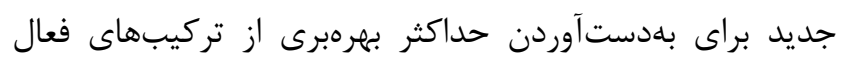

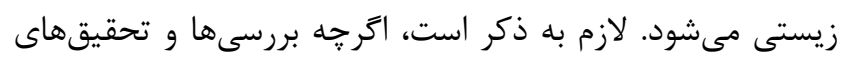
بسيارى در زمينهُ جستوجوى اثر بازدارندىى تركيبهاى

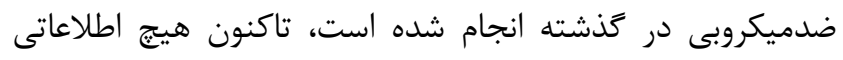

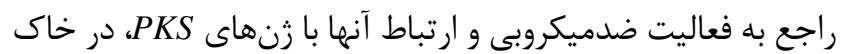

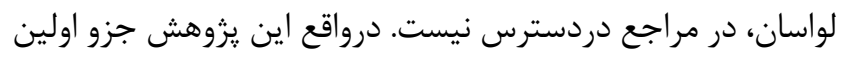

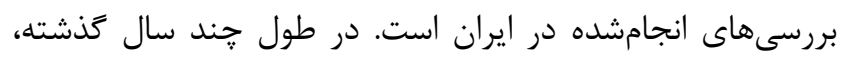

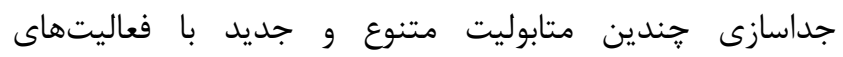

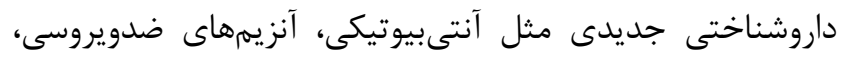

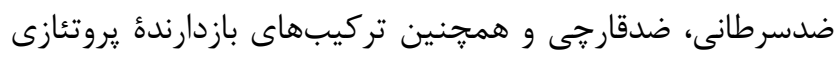

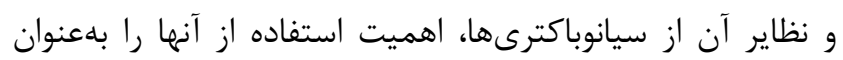

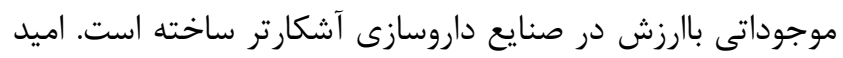

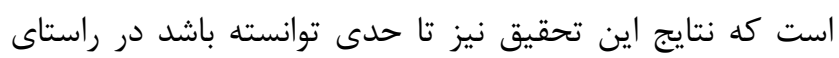

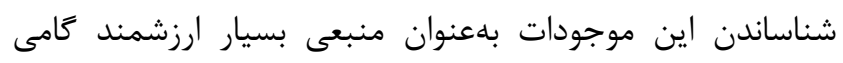
برداشته باشد.

\section{سياسگز ارى}

نويسندكان از تمامى كسانى كه در انجام اين تحقيق يارى

$$
\text { كردند كمال تشكر و قدردانى را بهعمل مى آئدرند. }
$$

$$
\text { تعارض منافع }
$$

بين نويسندًان تعارض در منافع كزارش نشده است.
فر آوردهاى طبيعى (خواص ضدميكروبى) اثبات شد. ديكر محققان

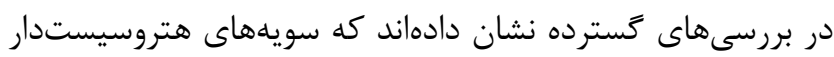

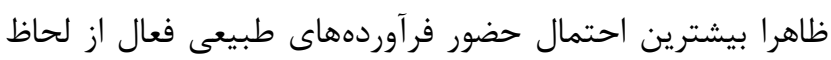

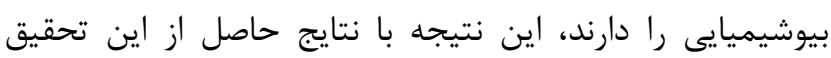
همخوانى دارد.

محققان بسيارى به جستوجوى زن يلى كتيدسنتاز در سيانو

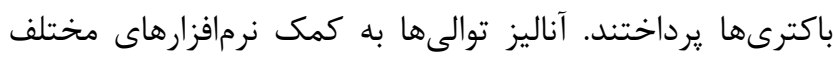

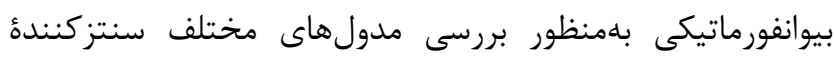
تركيبات غير يببوزومى و نقش هركدام در فعالسازى اسيدآمينه تا

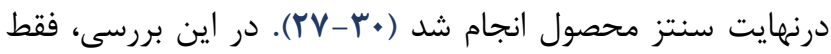

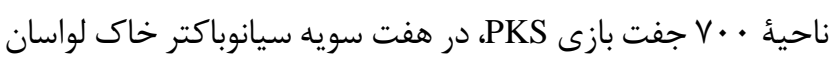
با استفاده از يرايمرهاى دزنره تكثير شد. سويههاى موردمطالعه در درخت فيلوزنتيك با حمايت بالا با سويههاى هممنام خود در يك

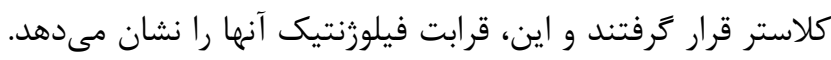

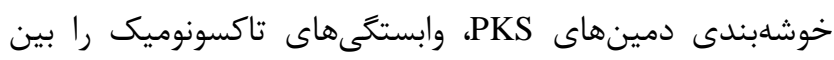

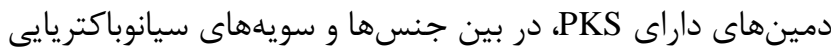

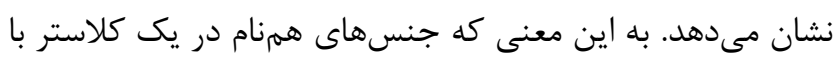

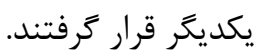

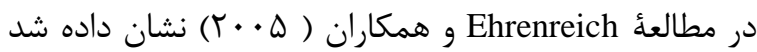
كه ارتباط مشخصى بين حضور اين زنها و فعاليتهاى بيوشيميايى

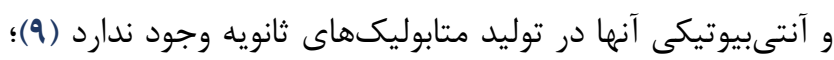

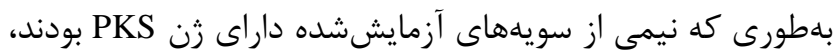

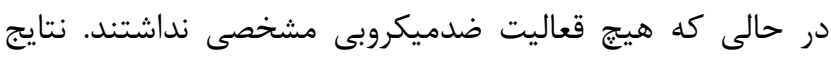

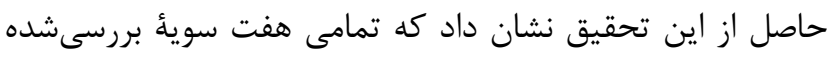

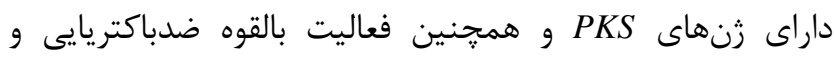
ضدقارجى بودند. نتايج ضدونقيض ديكر نشان داد كه دو دوائ سويه

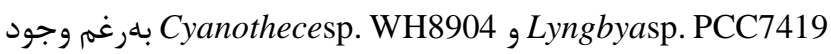

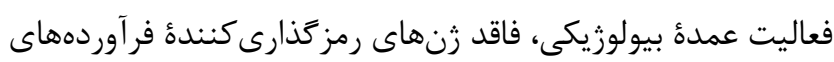

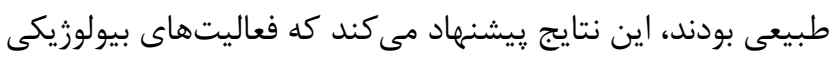




\section{References}

1. Shih PM, Wu D, Latifi A, Axen SD, Fewer DP, Talla E, Calteau A, Cai F, De Marsac NT, Rippka R, Herdman M. Improving the coverage of the cyanobacterial phylum using diversity-driven genome sequencing. Proceedings of the National Academy of Sciences. 2013; 110(3):

1053-8.

https://doi.org/10.1073/pnas.1217107110

2. Pancrace C, Gugger M, Calteau A. Genomics of NRPS/PKS Biosynthetic Gene Clusters in Cyanobacteria. Cyanobacteria: Omics and Manipulation. CAISTER ACADEMIC PRESS. 2017; 32: $55-74$.

3. Nowruzi B, Fahimi H, Ordodari N, Assareh R. Genetic analysis of polyketide synthase and peptide synthase genes of cyanobacteria as a mining tool for new pharmaceutical compounds. Journal of Pharmaceutical \& Health Sciences. 2017; 5(2): 139-50.

4. Rastogi RP, Sinha RP. Biotechnological and industrial significance of cyanobacterial secondary metabolites. Biotechnol Adv. 2009; 27(4): 521-39. https://doi.org/10.1016/j.biotechadv.2009.04.009

5. Tan LT. Bioactive natural products from marine cyanobacteria for drug discovery. Phytochemistry. 2007; 68(7): 954-79. https://doi.org/10.1016/j.phytochem.2007.01.012

6. Liu L, Jokela J, Wahlsten M, Nowruzi B, Permi P, Zhang YZ, et al. Nostosins, trypsin inhibitors isolated from the terrestrial cyanobacterium Nostoc sp. strain FSN. Journal of natural products. 2014; 77(8): 1784-90. https://doi.org/10.1021/np500106w

7. Komárek J, Kaštovský J, Mareš J, Johansen JR. Taxonomic classification of cyanoprokaryotes (cyanobacterial genera) Taxonomic classification of cyanoprokaryotes (cyanobacterial genera) 2014, using a polyphasic approach. Preslia. 2014; 86: 295-33.

8. Maneeruttanarungroj C, Incharoensakdi A. Rapid method for DNA isolation from a tough cell wall green alga Tetraspora sp. CU2551. World J Microbiol Biotechnol. 2016; 32(6):99. https://doi.org/10.1007/s11274-016-2055-y

9. Ehrenreich IM, Waterbury JB, Webb EA. Distribution and diversity of natural product genes in marine and freshwater cyanobacterial cultures and genomes. Appl Environ Microbiol. 2005; 71(11): 7401-13. https://doi.org/10.1128/AEM.71.11.7401-7413.2005

10. Nowruzi B, Blanco S, Nejadsattari T. Chemical and Molecular Evidences for the Poisoning of a Duck by Anatoxin-a, Nodularin and Cryptophycin at the Coast of Lake Shoormast (Mazandaran Province, Iran). Int J Algae. 2018; 20(4). https://doi.org/10.1615/InterJAlgae.v20.i4.30
11. Espinel-Ingroff A. Standardized disk diffusion method for yeasts. Clin Microbiol Newsl. 2007; 29(13): 97-100. https://doi.org/10.1016/j.clinmicnews.2007.06.001

12. Nowruzi B, Khavari-Nejad RA, Sivonen K, Kazemi B, Najafi F, Nejadsattari T. Identification and toxigenic potential of a Nostoc sp. Algae. 2012; 27(4): 303-13. https://doi.org/10.4490/algae.2012.27.4.303

13. Khairy HM, El-Kassas HY. Active substance from some blue green algal species used as antimicrobial agents. Afr J Biotechnol. 2010; 9(19): 2789-800.

14. El-Sheekh MM, Dawah AM, El-Rahman AM, El-Adel HM, El-Hay RA. Antimicrobial activity of the cyanobacteriaAnabaena wisconsinense andOscillatoria curviceps against pathogens of fish in aquaculture. Ann Microbiol. $\quad 2008 ; \quad 58(3): \quad 527$. https://doi.org/10.1007/BF03175553

15. Thillairajasekar K, Duraipandiyan V, Perumal P, Ignacimuthu S. Antimicrobial activity of Trichodesmium erythraeum (Ehr)(microalga) from south East coast of Tamil Nadu, India. Int J Integr Biol. 2009; 5(3): 167-70.

16. Kumar K, Mella-Herrera RA, Golden JW. Cyanobacterial heterocysts. Cold Spring Harbor perspectives in biology. 2010; 2(4): a000315. https://doi.org/10.1101/cshperspect.a000315

17. Kaushik P, Chauhan A. In vitro antibacterial activity of laboratory grown culture of Spirulina platensis. Indian J Microbiol. 2008; 48(3): 348-52. https://doi.org/10.1007/s12088-008-0043-0

18. Nowruzi B, Khavari-Nejad RA, Sivonen K, Kazemi B, Najafi F, Nejadsattari T. Identification and toxigenic potential of a cyanobacterial strain (Stigomena sp.). Progress in Biological Sciences. 2013; 3(1): 79-85.

19. Nowruzi B, Haghighat S, Fahimi H, Mohammadi E. Nostoc cyanobacteria species: A new and rich source of novel bioactive compounds with pharmaceutical potential. J Pharm Health Serv Res. 2018; 9(1): 5-12. https://doi.org/10.1111/jphs.12202

20. Asthana RK, Tripathi MK, Srivastava A, Singh AP, Singh SP, Nath G, et al. Isolation and identification of a new antibacterial entity from the Antarctic cyanobacterium Nostoc CCC 537. J Appl Phycol. 2009; 21(1): 81. https://doi.org/10.1007/s10811-008-9328-2

21. Abdel-Raouf N, Ibraheem IB, Abdel-Tawab S, Naser YA. Antimicrobial and antihyperlipidemic activities of isolated quercetin from Anabaena aequalis 1. J Phycol. 2011; 47(4): 955-62. https://doi.org/10.1111/j.1529-8817.2011.01020.x

22. Martins RF, Ramos MF, Herfindal L, Sousa JA, Skærven K, Vasconcelos VM. Antimicrobial and cytotoxic assessment of marine cyanobacteria- 


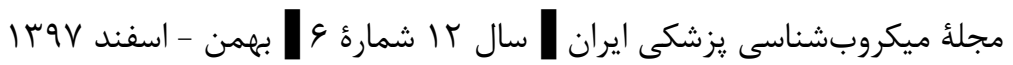

Synechocystis and Synechococcus. Mar Drugs. 2008; 6(1): 1-11. https://doi.org/10.3390/md6010001

23. Agger SA, Lopez-Gallego F, Hoye TR, SchmidtDannert C. Identification of sesquiterpene synthases from Nostoc punctiforme PCC 73102 and Nostoc sp. strain PCC 7120. J Bacteriol. 2008; 190(18): 6084-96.

24. Singh RK, Upadhyay S, Tiwari SP, Rai AK, Mohapatra TM. Screening of cyanobacterial extracts against bacteria causing nosocomial infections. J Pharm Res. 2010; 3(2096): e8.

25. Sethubathi GV, Prabu VA. Antibacterial activity of cyanobacterial species from adirampattinam coast, southeast coast of palk bay. Current Research Journal of Biological Sciences. 2010; 2(1): 24-6.

26. Abedin RM, Taha HM. Antibacterial and antifungal activity of cyanobacteria and green microalgae. Evaluation of medium components by Plackett-Burman design for antimicrobial activity of Spirulina platensis. Global Journal of Biotechnology and Biochemistry. 2008; 3(1): 22-31.
27. Zhao J, Yang N, Zeng R. Phylogenetic analysis of type I polyketide synthase and nonribosomal peptide synthetase genes in Antarctic sediment. Extremophiles. 2008; 12(1): 97-105. https://doi.org/10.1007/s00792-007-0107-9

28. Humisto A, Jokela J, Liu L, Wahlsten M, Wang H, Permi P, et al. The swinholide biosynthesis gene cluster from a terrestrial cyanobacterium, Nostoc sp. strain UHCC 0450. Appl Environ Microbiol. 2018; 84(3): e02321-17.

29. Roulet J, Taton A, Golden JW, Arabolaza A, Burkart MD, Gramajo H. Development of a cyanobacterial heterologous polyketide production platform. Metabolic engineering. $\quad 2018 ; \quad$ 49: 94-104. https://doi.org/10.1016/j.ymben.2018.07.013

30. Dittmann E, Gugger M, Sivonen K, Fewer DP. Natural product biosynthetic diversity and comparative genomics of the cyanobacteria. Trends Microbiol. 2015; 23(10):

642-52. 